\title{
Effects on Load-Frequency Control of a Solar Power System with a Two-Area Interconnected Thermal Power Plant and its Control with a New BFA Algorithm
}

\author{
Zafer Civelek ${ }^{1}$, Goksu Gorel ${ }^{2}$, Murat Luy ${ }^{3}$, Necaattin Barısci ${ }^{4}$, Ertugrul Cam ${ }^{3}$ \\ ${ }^{1}$ Electronics and Automation Department, Cankiri Karatekin University, \\ 18200, Cankiri, Turkey \\ ${ }^{2}$ Electric and Energy Department, Cankiri Karatekin University, \\ 18200, Cankiri, Turkey \\ ${ }^{3}$ Department of Electrical and Electronics Engineering, Kirikkle University, \\ 71450, Kirikkale, Turkey \\ ${ }^{4}$ Department of Computer engineering, Gazi University, \\ 06500, Ankara, Turkey \\ goksugorel@karatekin.edu.tr
}

\begin{abstract}
A control operation is the most important part of stabilization between load and frequency in a power system. The demand power change and the generated power change can disrupt the load-frequency balance. For this reason, the system frequency value should be controlled by some methods. In this study, a load frequency control was performed in a twoarea power system. The renewable solar energy system and the interconnected power system were connected. In order to control the load-frequency balance, the classical PI, PID, Fuzzy Logic Controller (FLC) based PI and Bacterial Foraging Algorithm (BFA) based PI controller were separately designed and implemented to control the frequency value. All the trials were simulated and confirmed by the MATLAB/Simulink program. According to the results obtained from the control methods, the BFA-PI method provided better overshoots and BFA-PI had better settling times than the others.
\end{abstract}

Index Terms-Automatic generation control; Fuzzy control; Optimization; Power system stability.

\section{INTRODUCTION}

Energy demand is increasing as a result of the rapid industrialization in the world. As the conventional energy sources are limited, energy is becoming an important component. Electricity energy cannot be stored with high capacity, thus, the produced and consumed energy should always be equal [1], [2]. Frequency is the most important parameter of the stability of a power system. The aim here is to keep the power system in a normal operational status. Normal operational status consists of three parts. The first one is compensation of sudden load changes. The second one is meeting the active-reactive power balance. The third one is stable frequency [3].

An interconnected power system consists of several production-consumption centres that work in harmony with

Manuscript received 4 March, 2018; accepted 7 August, 2018. each other. The stable operation of an interconnected grid depends on a balance between production and consumption centres [4], [5]. If there is an incompatibility between the power produced by generators that are connected to the grid and the power demanded by the load in stable operation, a change would occur in the operating frequency of the system. If the produced energy is greater than the consumed energy, the frequency increases; however, if the situation is vice versa, the frequency decreases. It is possible to take this difference to the level of zero by checking the speed of a turbine which moves the generator [6], [7]. The frequency value has to be between $49.2 \mathrm{~Hz}$ and $50.8 \mathrm{~Hz}$, which is the international range according to the Union for the Coordination of the Transmission of Electricity (UCTE). The frequency value, which is $50 \mathrm{~Hz}$ in Turkey, must be within the legal limits for the continuity of this connection to UCTE. This also reveals an importance of load frequency control for interconnected grids [8].

Recently, different methods have been used to maintain the process of load frequency control. In a study by Cam et al., a load frequency control in a two-area interconnected grid was maintained by conventional PI, fuzzy logic and PI controller programmed with fuzzy logic [1], [9], [10]. Additionally, in the literature some studies designed PID controllers that were set with the particle swarm optimization (PSO) method [11]. A similar study was achieved by applying an artificial neural grid (ANN) based controller to a three-zone interconnected grid [12], [13]. However, these studies were conducted on interconnected grids through conventional generator units. In this article, a solar energy plant, whose number has increased recently, was modelled and included in a two-area interconnected grid. The load-frequency balance was provided by PI, PID, BFA-PI and FLC-PI controllers, in which changing climatic conditions and sudden power decreases were taken into 
account. The number of parameters controlled in the multizone power systems was exceeded. The increase in the number of parameters was applied and the control process were complicated. Thus, the frequency value was balanced in different power areas. Moreover, smart fuzzy logic controllers were designed to provide the frequency stability of multi-zone systems [14], [15]. Some studies were carried out in the literature in some specific areas integrated with solar energy. In a study, hysteresis control was achieved with fixed switching frequency. The hysteresis control was emphasised in the study by using a fixed switching frequency [16]. There are some studies in the literature on interconnection systems where wind turbines were used as a source of renewable energy. A study by Sharma et al. used the Symbiotic organisms search algorithm for LFC [17].

The study examined the impacts of solar energy plants, which are potentially the most common among the renewable energy sources, on the frequency value as a result of the inclusion to the two-area interconnected grid. As the operating conditions of solar energy plants are not the same as those of conventional fuel plants, they need a load frequency control. There is a rapid instability between the produced and the consumed energy values as a result of being climatic conditions and sudden decrease in the produced power value. This event could be observed more frequently in the areas with the possibility of sudden climatic condition changes. Generally, up to now, loadfrequency control studies of modern control strategies with traditional energy sources were used. On the other hand, in interconnected grids that integrate solar energy systems, there are no studies on usage of modern techniques such as a FLC-PI. In this article, as an innovation about loadfrequency control, BFA-PI and FLC-PI were designed as controllers in an interconnected grid with solar energy for a frequency correction.

\section{Photovoltaic Power Model}

A circuit model requires simulation of PV solar cells. Various models have been created since 1960s up to now [18]. Solar cells depend on variable light intensity and temperature on PV cells connected in serial or parallel. Their general static equivalent circuit model is represented by a dynamic characteristic, which is formed to meet the changes. Formation of a model such as the dynamic model has been an important issue for researchers for a long time [19], [20]. The simplest equivalent circuit of a PV solar cell is shown in Fig. 1(a). The solar cell is illustrated by a current source $I_{\text {ph }}$ in Fig. 1(a). The current source shows the current, which is obtained by the effects of photons that come from daylight. $I_{D}$ represents the inverse saturation current that occurs in the PV solar cell, while resistance represents the heat losses at the point $\mathrm{P}-\mathrm{N}$ point. The output voltage that is obtained from the circuit in Fig. 1(a) is shown in (1) [21]-[23]. Here, $A$ represents curve fitting factor, $k$ represents Boltzmann constant, $T_{\text {cell }}$ represents reference cell operating temperature, $e$ represents electron charge, $I_{p h}$ represents photocurrent, $I_{0}$ represents reverse saturation current of diode and $I_{\text {cell }}$ represents Cell output current.

Figure 1(b) and Fig. 1(c) show the panel I-V and P-V characteristics obtained from the solar cell modelled according to (1)

$$
V_{\text {cell }}=\left(\left(A \times k \times T_{\text {cell }}\right) \times e\right) \times \ln \left(\left(I_{p h}+I_{0}+I_{\text {cell }}\right) \times I_{0}\right) .
$$

\section{TWO-AREA POWER SYSTEM}

Synchronous generators are placed to provide power for the loads connected to the interconnected grid. However, diesel generators are used for the systems which are independent from the grid. The generators running with turbines are used in larger interconnected grids. The transfer functions used in the modelling of a turbine and a generator are given in (2) and (3) [24]. Here, $G_{T(s)}$ represents the turbines transfer function, $G_{G(s)}$ represents the generators transfer function, $T_{G(s)}$ represents speed governor time constant and $T_{T(s)}$ represents Turbine time constant:

$$
\begin{gathered}
G_{G(s)}=1 /\left(T_{G(s)}+1\right), \\
G_{T(s)}=1 /\left(T_{T(s)}+1\right) .
\end{gathered}
$$

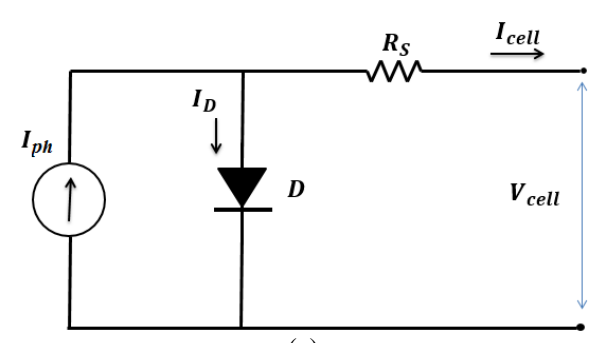

(a)
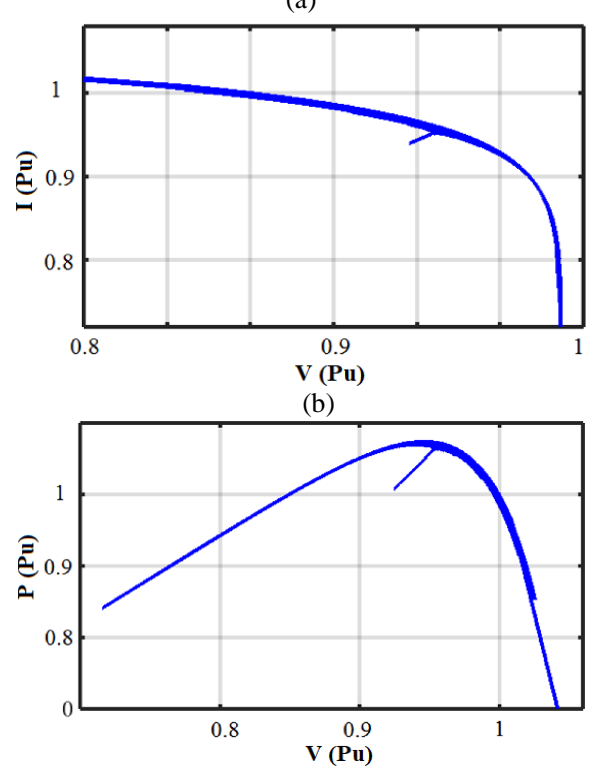

(c)

Fig. 1. Solar cells are reduced to the simplest equivalent circuit (a); solar cell I-V characteristic (b); solar cell P-V characteristic (c).

Frequency stability is the ability to keep the frequency stable after rapid changes, which cause instability between the produced and demanded powers in the system. The total power $\left(P_{1}\right)$ in the first area is equal to the sum of the power of the generator $\left(P_{\mathrm{G} 1}\right)$ and the solar energy systems $\left(P_{\mathrm{V} 1}\right)$. It is given in (4)

$$
P_{1}=P_{G_{1}}+P_{V 1}
$$

Power balance $\left(P_{\Delta i}\right)$ is disrupted when an inequality occurs either in the load side or in the production side. Here, $P_{L 1}$ refers to the load change in the first area 


$$
P_{\Delta 1}=P_{1}+P_{L 1}
$$

If $P_{\Delta}$ has a nonzero value, the frequency of the system would change. Frequency change $\left(\Delta_{\omega}\right)$ is expressed in (6). Here, $K_{S}$ is defined as the characteristic constant of the system frequency in the first area

$$
\Delta_{\omega}=P_{\Delta 1} / K_{S}
$$

The transfer function, which represents the load changes that have impact on the system frequency, is presented in (7) [11]. Here, $\mathrm{M}=2 \times \mathrm{H}$ and $\mathrm{H}$ represents inertia constant

$$
G_{L}=1 / M_{(s)}+1
$$

The two-area renewable interconnected system used for this article is illustrated in Fig. 2. This interconnected power system consists of various components. The load-frequency control in this grid, in which the solar energy system is included, would ensure a balanced system. A control flow diagram was designed as indicated in Fig. 3. The MATLAB/Simulink program was used in this design.

A transmission line model that connects the two areas to each other was used in this design. The situations where loads changed were examined in this newly designed interconnected power system. Moreover, in order to take into account any variation in the climatic conditions there were increases and decreases depending on time in the power generated by the photovoltaic (PV) power system. The load-frequency control system, which had all these parameters, was operated in two different ways.

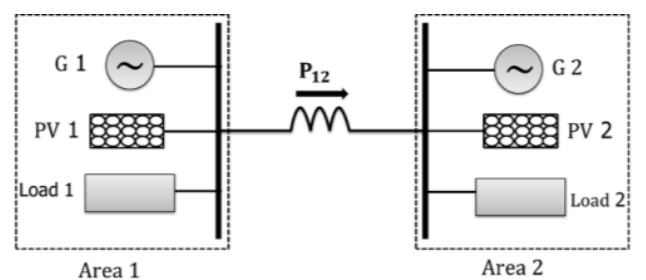

Fig. 2. Two-area interconnected grid schemas: (a) block diagram of the system in two interconnected areas; (b) two-area interconnected grid connection.

The primary frequency control is the frequency control, in which the power balance is achieved by setting the turbine speed regulator when the electricity energy is different in two different areas. The secondary frequency control is achieved by reducing the permanent frequency error to zero in the interconnected grid by controlling the power flow between the areas. Figure 3 shows the block diagram of the two-area interconnected grid with the PV power system. Here, the PV power is modelled as a $\mathrm{Pu}$ system. The power generated by the PV system was assessed. It was not needed to model converter.

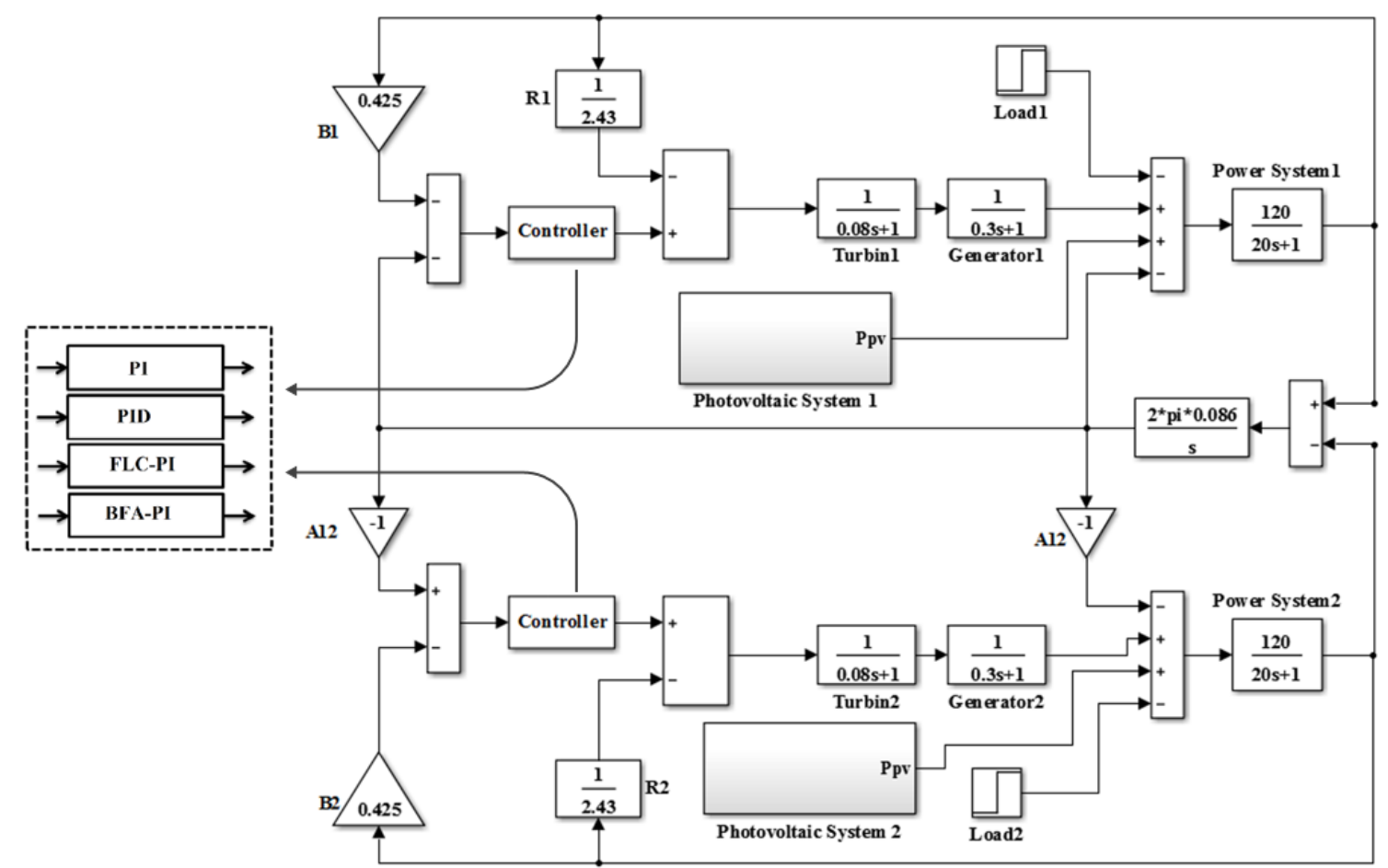

Fig. 3. Two-area interconnected grid block diagram with PV power system.

Area control error $\left(A C E_{i}\right)$, which is required for frequency control, could be calculated as in (8)

$$
A C E_{1}=\left(-\Delta P_{12}-b_{1} \times \Delta \omega\right),
$$

where $b_{1}$ in (8) refers to the frequency bias. In other words, it is the expression of the change in the frequency $(\Delta \omega)$ in the power unit, and it is obtained with (9) [12], [25]

$$
b_{1}=1 / R_{1}+D_{1} \text {. }
$$

Parameters of the Two-Area power system in the solar power system were taken from the literature [26].

\section{CONTROLLERS}

\section{A. Conventional PI and PID Controllers}

P, PI and PID control methods are preferred mostly in load-frequency control studies in literature. Even if these studies seem to be enough, rapid climate changes and load fluctuations cause unstable systems [27], [28]. Controller 
blocks need two types of signal in load-frequency control. The first one is the steady-state error. The second error is the value which represents the temporary overshoots. The temporary situation emerges in the time of excessive rise or fall in the frequency in sudden deflections. In this study, the performance of conventional and modern control techniques for load-frequency control in an interconnected power system with a two-area solar energy system is presented. During the control process, the Ziegler Nichols (ZN) method was applied for PI and PID, which are the conventional controllers, and its simulation was carried out. The parameters used in the two-area interconnected power system that was modelled are given in Fig. 3.

The expression that belongs to the control signal $\left(u_{(t)}\right)$ which is required for the PI and PID controller is shown in (10). $K_{P}$ represents control area gain

$$
u(t)=K_{p}\left\lfloor e(t)+\left(1 / T_{i}\right) \int_{0}^{t} e(t) d t+T_{d}(e(t) / d t)\right\rfloor
$$

\section{B. Controller Designed with FLC-PI}

It is difficult to apply the controls defined by conventional methods such as the ZN method to flexible and continuously changing systems. The parameters of these controls remaining constant are a disadvantage

$$
u_{p i}(t)=\left\lfloor-K_{p} \times A C E_{i}-\int K_{i}\left(A C E_{i}\right) d t\right\rfloor .
$$

On the other hand, a conventional control that is optimised and applied to the system is recommended for continuously changing systems. Here, the PI controller that was set with the fuzzy logic was used. It is given in (11). Thus, the control of the system was achieved in a more flexible way in comparison to conventional control systems. The error and the change of error utilised to set the PI controller are given in the block scheme in Fig. 4.

The membership functions employed in the FLC-PI controller and the ranges of these functions are shown in Fig. 5. These values are necessary for FLC-PI, which sets the PI controller [26], [29]-[31]. Fuzzy logic rules for FLCPI controller are shown in Table I.

\begin{tabular}{|c|c|c|c|c|c|c|c|}
\hline \multicolumn{8}{|c|}{ Fuzzy Logic Rules } \\
\hline \multirow{2}{*}{ ACE } & \multicolumn{7}{|c|}{$\Delta \mathrm{ACE}(\mathrm{k})$} \\
\hline & $N_{L}$ & $N_{M}$ & $N_{S}$ & Z & $P_{S}$ & $P_{M}$ & $P_{L}$ \\
\hline$N_{L}$ & $P_{L}$ & $P_{L}$ & $P_{L}$ & $P_{L}$ & $P_{M}$ & $P_{M}$ & $P_{S}$ \\
\hline$N_{M}$ & $P_{L}$ & $P_{M}$ & $P_{M}$ & $P_{M}$ & $P_{S}$ & $P_{S}$ & $P_{S}$ \\
\hline$N_{S}$ & $P_{M}$ & $P_{M}$ & $P_{S}$ & $P_{S}$ & $P_{S}$ & $P_{S}$ & Z \\
\hline Z & $N_{S}$ & $N_{S}$ & $N_{S}$ & Z & $P_{S}$ & $P_{S}$ & $P_{S}$ \\
\hline$P_{S}$ & Z & $N_{S}$ & $N_{S}$ & $N_{S}$ & $N_{S}$ & $N_{M}$ & $N_{M}$ \\
\hline$P_{M}$ & $N_{S}$ & $N_{S}$ & $N_{M}$ & $N_{M}$ & $N_{M}$ & $N_{L}$ & $N_{L}$ \\
\hline$P_{L}$ & $N_{S}$ & $N_{M}$ & $N_{L}$ & $N_{L}$ & $N_{L}$ & $N_{L}$ & $N_{L}$ \\
\hline
\end{tabular}

TABLE I. FUZZY LOGIC RULES FOR FLC-PI CONTROLLER

Note: $N_{L}$ : large negative, $N_{M}$ : medium negative, $N_{S}:$ small negative, $\mathrm{Z}$ : zero, $P_{S}$ : small positive, $P_{M}:$ medium positive, $P_{L}$ : large positive.

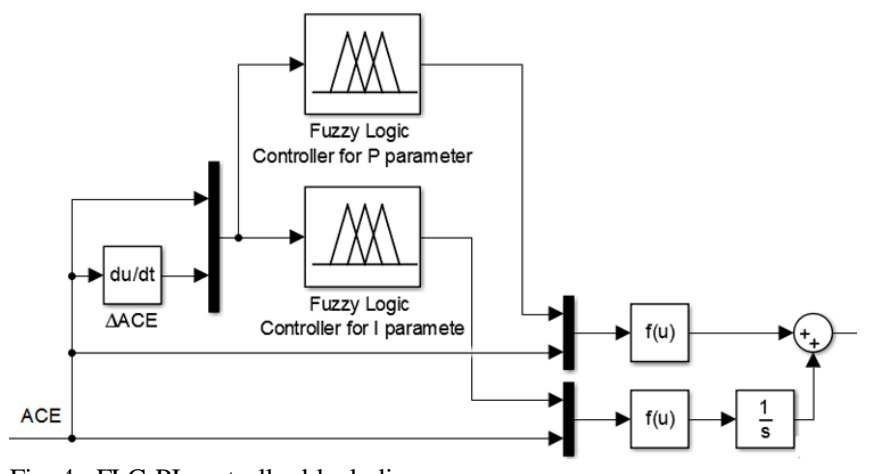

Fig. 4. FLC-PI controller block diagram.
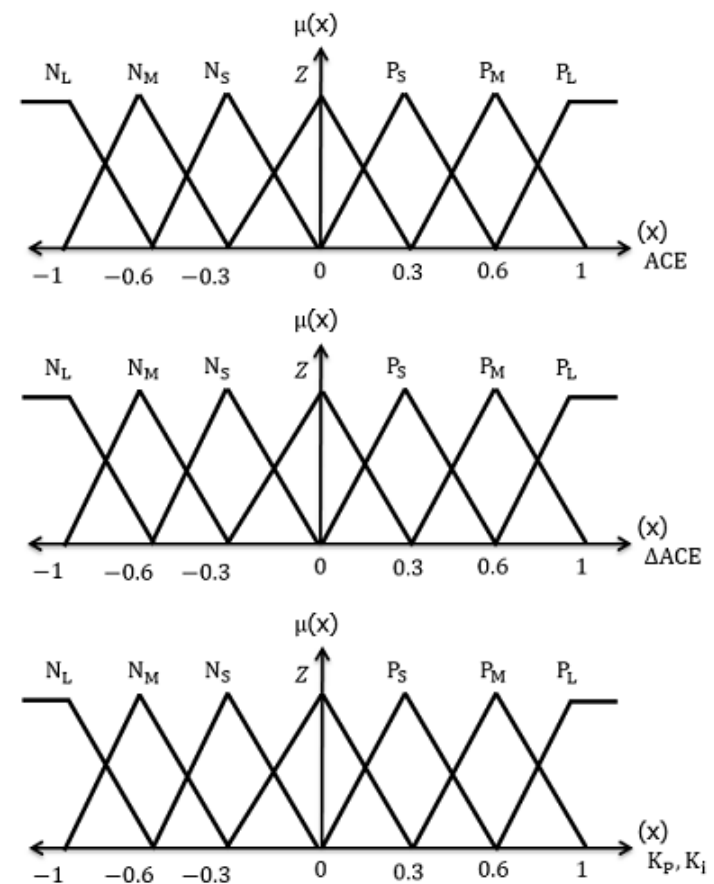

Fig. 5. Membership function for the FLC-PI controller.

\section{Controlled Designed with BFA-PI}

The basis of Bacteria Foraging Optimization was laid by Escherichia Coli, taking into account the processes that bacteria use in their nutritional search methods. BFA, based on a stochastic search technique, is the most effective method that considers population. The approach in this algorithm is inspired by the physical and biological life of bacteria. The first step in BFA is to transform the problem into the most appropriate algorithm. The second most important step is to arrange the bacteria according to the herd information. As a final step, it can be thought of as an optimal solution search [32]. An iteration of BFA comes from four basic stages. These are Chemotaxis, swarming, Reproduction and Elimination-Dispersal. The flow diagram of BFA is shown in Fig. 6.

Chemotaxis: A chemotactic step can be assigned as a tumble followed by a tumble or a tumble followed by a run lifetime. To symbolise a tumble, a unit length random way $(j)$ is created. This will be used to describe the direction of movement after a tumble. The formula for changing direction in BFA can be defined as in (12). Where $i(j, k, l)$ represents the $i$ 'th bacterium at $j$ 'th chemotactic, $k$ 'th reproductive and $i$ 'th elimination and dispersal step. $\mathrm{C}_{(\mathrm{i})}$ is the size of the step taken in the random direction specified by a tumble [33]. 
TABLE II. PI COEFFICIENTS OBTAINED WITH THE PROPOSED METHODS.

\begin{tabular}{|c|c|c|}
\hline Controller & $K_{p}$ & $K_{i}$ \\
\hline BFA-PI & 0.96 & 0.5421 \\
\hline
\end{tabular}

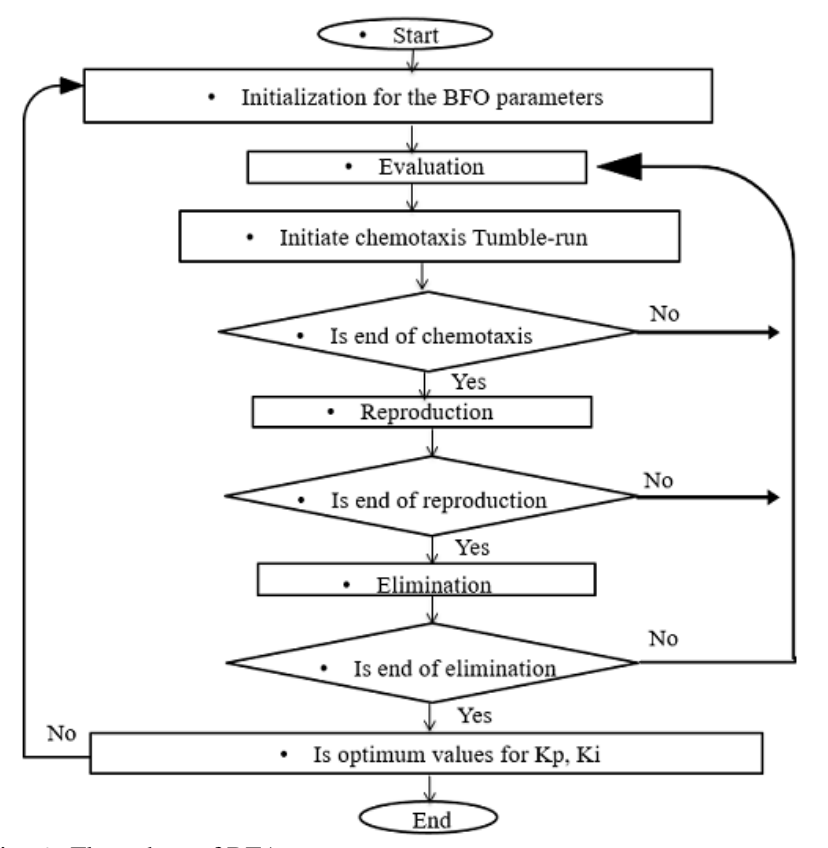

Fig. 6. Flow chart of BFA.

$$
i(j+1, k, l)=i(j, k, l)+C(i) \times(j) .
$$

Swarming: Bacteria used in the optimization process need to attract other bacteria to reach the areas that are the richest in terms of food. Thus, a faster association is achieved. To achieve this, a penalty function based on the optimal bacteria and the relative distances of each bacterium until the call is added to the original cost function. In the last step, when all the bacteria enter the solution zone, the penalty function becomes zero.

Reproduction: In the next step, evolved by several chemotactic stages, the original set of bacteria reaches the reproduction phase. At this stage, the best bacteria set is divided into two groups. Half of the healthy bacteria are replaced by half of the other bacteria. In this phase, removal is made from the centre due to poor manager qualities. This keeps the bacteria population constant during the evolution process [34].

Elimination and dispersal: Sudden and unpredictable events may occur in BFA. This may greatly alter the smooth process of evolution and cause the set of bacteria to be removed from the centre and/or dispersed into a new environment. Most ironically, instead of disrupting the normal chemotactic growth of the bacteria set, it may place a newer set of bacteria close to the food location. Elimination and dispersal are parts of the long-range movement behaviour on the population level. In implementing optimization, it helps to reduce stagnation behaviour, which is common in such parallel search algorithms. The $\mathrm{K}_{\mathrm{p}}$ and $\mathrm{K}_{\mathrm{i}}$ coefficients obtained using BFA are shown in Table II. The parameters that BFA possesses are as follows: The dimension of the search space is 2 , the number of the bacteria is 10 , the number of the chemotactic steps is 5 , the limits of the length of a swim is 10 , the number of elimination-dispersant events is 2 , the number of bacteria reproductions is $1 / 2$ and the respective probabilities of bacteria (eliminated) are 0.25 .

\section{RESULTS}

In this study, the load-frequency control of a two-area interconnected power system, which included solar panels that are under the effect of climatic changes, was achieved. During the controlling process, the controllers were simulated separately in the designed system. Firstly, the conventional PI and PID controllers were modelled. The simulation was performed with FLC-PI and BFA-PI, which were modernised with fuzzy logic apart from the conventional controllers. During the simulation, the power obtained from the solar panels indicated changes due to the weather conditions in Fig. 7.
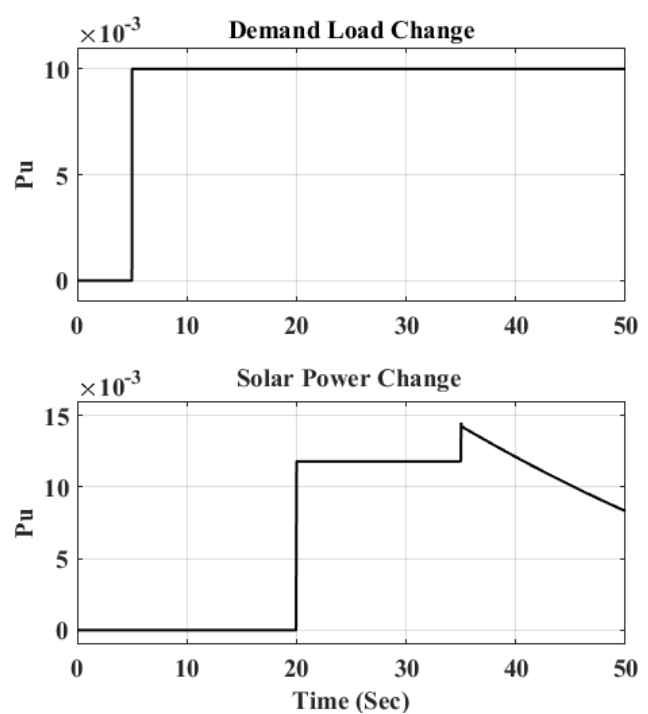

Fig. 7. Load power change and solar power change depending on weather conditions.

Besides, these power changes affect the interconnected grid as "load changes". The parameters operated in the interconnected grid, which was modelled by including renewable energy, are shown in Fig. 3.

The decrease in the power demand of the load, the activation of the solar energy system and the power-time change intended for the regular power loss in the PV panels are demonstrated in Fig. 7. While operating the control process, a drastic action was taken into account to change the frequency in three different times. The first change was the sudden power loss with $0.01 \mathrm{pu}$ in the fifth second at point A in Fig. 8(a). The second change was the inclusion of the power obtained from the solar energy system in the interconnected grid at point B in Fig. 8(a). When the reaction of the system takes a stable position against this sudden frequency change, a power increase occurs in the renewable solar energy system in the 35th second due to the weather conditions at point $\mathrm{C}$ in Fig. 8(a). Right after this, the power that comes regularly from the PV power system starts to decrease due to the weather conditions.

The gain controls of the applied conventional controllers were designed in the range of $0 \mathrm{sec}-5 \mathrm{sec}$. These gain values are for $\mathrm{Kp}$ value of 1.1 and $\mathrm{Ki}$ value of 0.8 for PI, and $\mathrm{Kp}$ value of $1.4, \mathrm{Ki}$ value of 2.0 and $\mathrm{Kd}$ value of 0.1 for PID. 


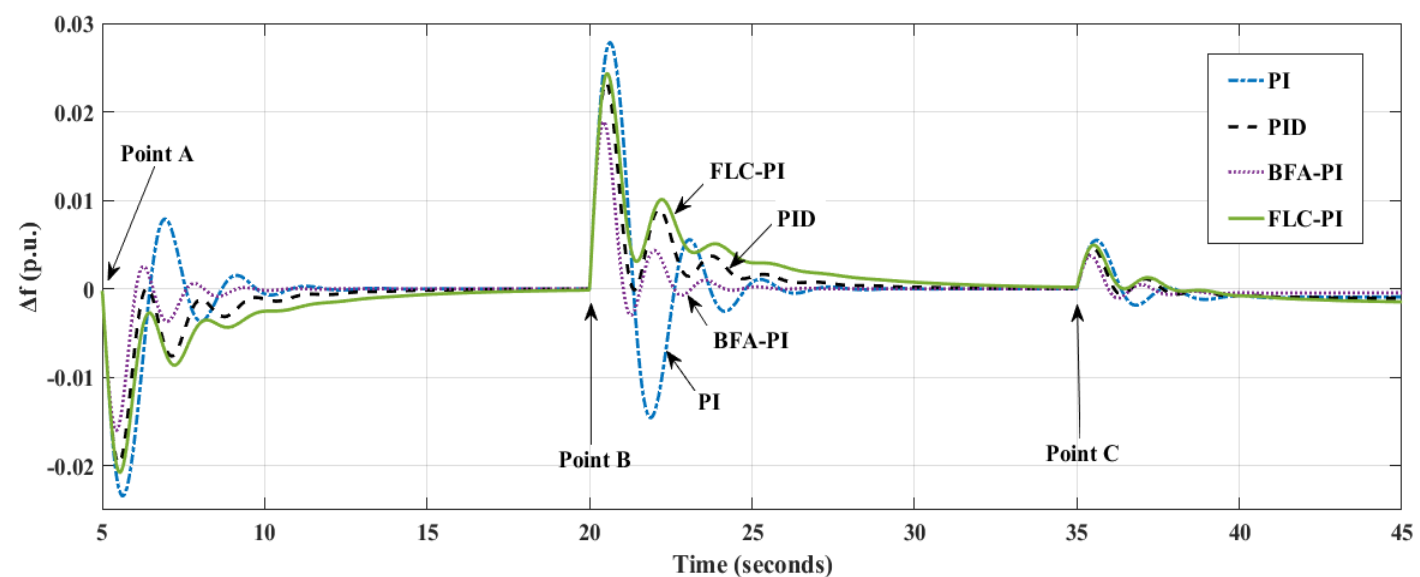

(a)

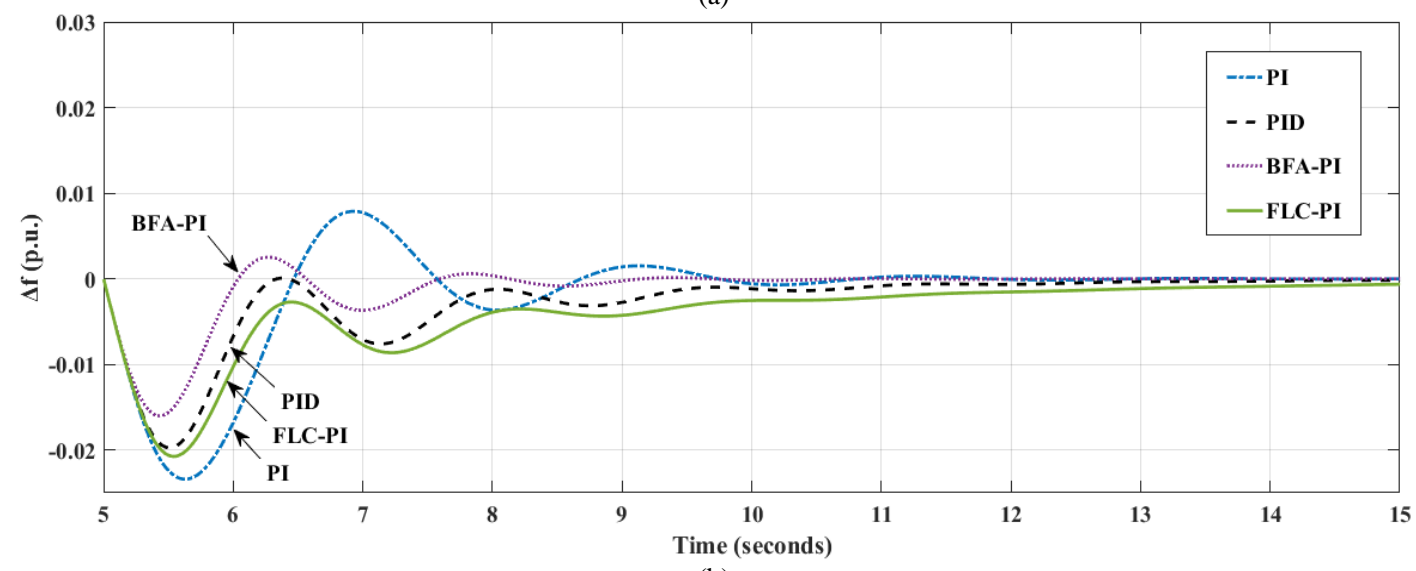

(b)

Fig. 8. Frequency change in entire simulation(a); frequency change during load increase (zoomed of point A) (b);

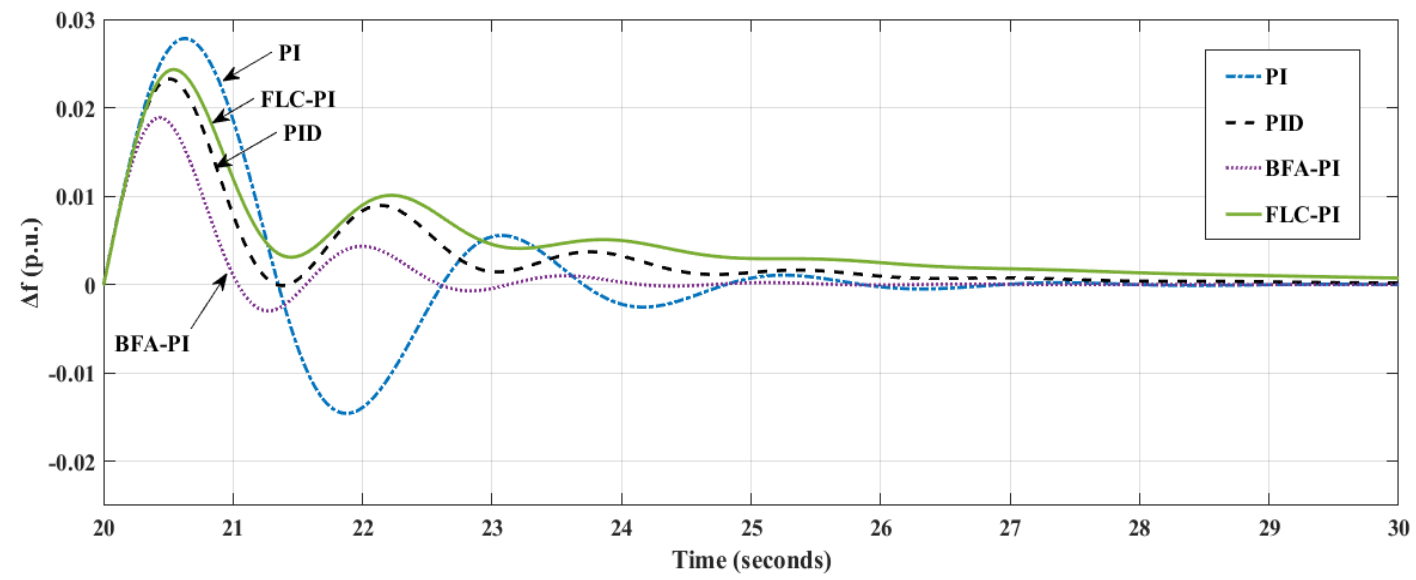

(a)

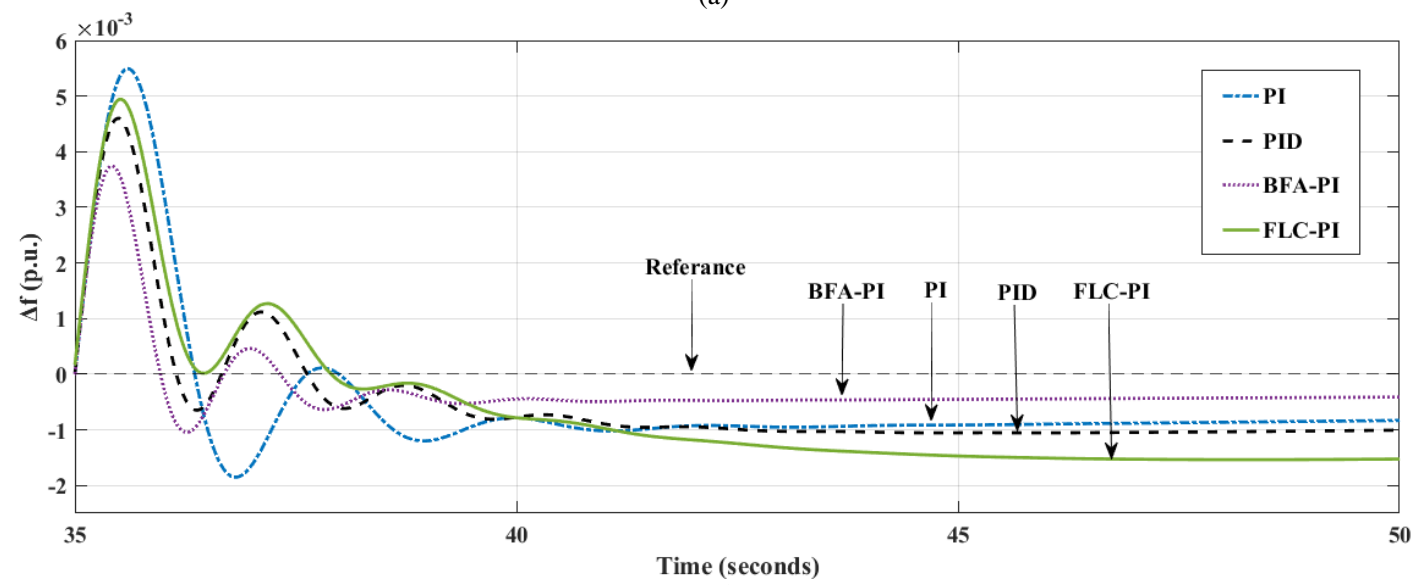

(b)

Fig. 9. Frequency change when solar power is suddenly inclided (zoomed of point B) (a); frequency change when solar power is in continuous reduction (shadowing effect) (zoomed of point C) (b). 
The frequency change results of the conventional controllers and the other recommended FLC-PI and BFA-PI controllers are shown in Table III, Table IV and Table V. The positive and negative overshoot values in the frequency values of a $0.01 \mathrm{pu}$ load reduction in the interconnected grid in the 5th second are shown in Table III and Fig. 8(b). As it is seen in this comparative table, there is no positive fluctuation in the FLC-PI controllers.

TABLE III. FREQUENCY CHANGE IN LOAD REDUCTION OF 0.01PU. (POINT A).

\begin{tabular}{|c|c|c|}
\hline Controllers & $\begin{array}{c}\text { Negative maximum } \\
\text { Overshoots }\end{array}$ & $\begin{array}{c}\text { Positive maximum } \\
\text { overshoots }\end{array}$ \\
\hline PI & $-23 \times 10^{-3}$ & $8 \times 10^{-3}$ \\
\hline PID & $-20 \times 10^{-3}$ & $1 \times 10^{-3}$ \\
\hline FLC-PI & $-20 \times 10^{-3}$ & - \\
\hline BFA-PI & $-16 \times 10^{-3}$ & $2 \times 10^{-3}$ \\
\hline
\end{tabular}

The frequency fluctuations related to the changes in the 20th and the 30th seconds which define sudden power increases depending on the solar radiation in the interconnected renewable grids are shown in Fig. 9(a). Thus, the most remarkable result was the performance of BFA-PI in the control of load-frequency.

TABLE IV. FREQUENCY CHANGE IN SOLAR CHANGE OF 0.012 PU. (POINT B).

\begin{tabular}{|c|c|c|}
\hline Controllers & $\begin{array}{c}\text { Negative maximum } \\
\text { Overshoots }\end{array}$ & $\begin{array}{c}\text { Positive maximum } \\
\text { overshoots }\end{array}$ \\
\hline PI & $-15 \times 10^{-3}$ & $27 \times 10^{-3}$ \\
\hline PID & - & $23 \times 10^{-3}$ \\
\hline FLC-PI & - & $24 \times 10^{-3}$ \\
\hline BFA-PI & - & $8 \times 10^{-3}$ \\
\hline
\end{tabular}

TABLE V. STEADY-STATE ERROR IN THE FREQUENCY OF CONTINUOUS REDUCTION OF THE SOLAR ENERGY SYSTEM (POINT C).

\begin{tabular}{|c|c|}
\hline Controllers & Steady-State Error \\
\hline PI & $-9 \times 10^{-3}$ \\
\hline PID & $-1 \times 10^{-3}$ \\
\hline FLC-PI & $-1.5 \times 10^{-3}$ \\
\hline BFA-PI & $-0.5 \times 10^{-3}$ \\
\hline
\end{tabular}

The numerical results of the change in the frequency between the 35th and 50th seconds in Fig. 9(b) that led to a continuous decrease due to the adverse weather conditions in the PV energy system are depicted in Table V. It is seen that the BFA-PI controller minimised the steady-state error better than the other controllers in Fig. 9(b) and Table V.

The change in area control error throughout the entire simulation is shown in Fig. 10. This area control error was employed in the design of the proposed controls and it was defined as the most important variable in this study.

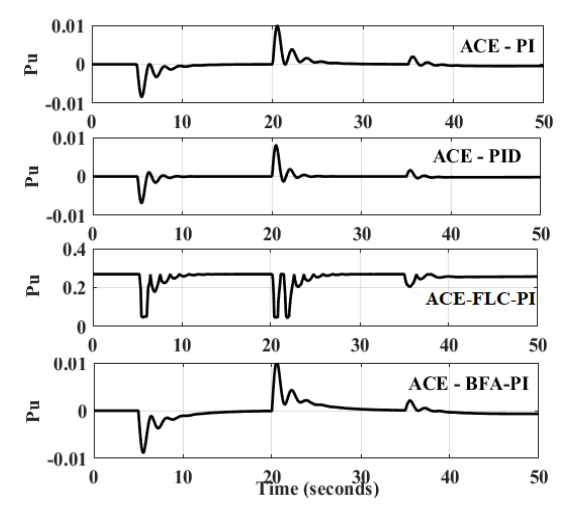

Fig. 10. ACE changes with different controllers.

\section{CONCLUSIONS}

In this study, a two-area interconnected power system with a Solar Power System was modelled by using mathematical models in order to investigate the effects of renewable energy sources on load-frequency control. Additionally, some modern control techniques called FLCPI and BFA-PI were also designed. Moreover, conventional PI and PID controllers were applied in the system to make comparisons with the others. All the controllers were implemented separately in order to set the varying frequency of the system to the nominal frequency during sudden load changes. According to the results, it was seen that the modern control techniques provided better results than the conventional controllers. In particular, the proposed BFA-PI controller had better values in terms of settling time and overshoot. Besides, it was seen that the proposed controllers could keep the steady-state errors in their nominal values. This situation was demonstrated prominently in the 35th second when there was a sudden drop in the power of the Solar energy system depending on the weather conditions. In conclusion, the study has shown that all the proposed methods could successfully maintain the frequency at the nominal value at load change points in comparison to other conventional methods.

\section{REFERENCES}

[1] E. Cam, I. Kocaarslan, "A fuzzy gain scheduling PI controller application for an interconnected electrical power system", Electric Power Systems Research, vol. 73, no. 3, pp. 267-274, 2005. DOI: 10.1016/j.epsr.2004.06.013.

[2] C. Chen, K. Zhang, K. Yuan, Z. Gao, X. Teng, Q. Ding, "Disturbance rejection-based LFC for multi-area parallel interconnected AC/DC system", IET Generation, Transmission \& Distribution, vol. 10, no. 16 , pp. $4105-4117,2016$. DOI: 10.1049 /iet-gtd.2016.0526.

[3] N. Sa-ngawong, I. Ngamroo, "Intelligent photovoltaic farms for robust frequency stabilization in multi-area interconnected power system based on PSO-based optimal Sugeno fuzzy logic control", Renewable Energy, vol. 74, pp. 555-567, 2015. DOI: 10.1016/j.renene.2014.08.057

[4] H. Gozde, M. C. Taplamacioglu, I. Kocaarslan, M. A. Senol, "Particle swarm optimization based pi-controller design to load-frequency control of a two area reheat thermal power system", Journal of Thermal Science and Technology, vol. 30, no. 1, pp. 13-21, 2010.

[5] H. M. Hasanien, A. A. El-Fergany, "Symbiotic organisms search algorithm for automatic generation control of interconnected power systems including wind farms", IET Generation, Transmission \& Distribution, vol. 11 , no. 7, pp. 1692-1700, 2017. DOI: $10.1049 /$ ietgtd.2016.1245

[6] I. Kocaarslan, E. Cam, "An adaptive control application in a large thermal combined power plant", Energy Conversion and Management, vol. 48, no. 1, pp. 174-183, 2007. DOI: 10.1016/j.enconman.2006.04.014.

[7] B. Anand, A. E. Jeyakumar, "Fuzzy logic based load frequency control of hydrothermal system with non-linearities", Electric Power Eng, vol. 3, pp. 112-118, 2009

[8] A. H. Chowdhury, M. Asaduz-Zaman, "Load frequency control of multi-microgrid using energy storage system", in 8th Int. Conf. Electrical and Computer Engineering, Dhaka, Bangladesh, 2014, pp. 548-551. DOI: 10.1109/ICECE.2014.7026975.

[9] E. Cam, "Application of fuzzy logic for load frequency control of hydroelectrical power plants", Energy Conversion and Management, vol. 48 , no. 4 , pp. 1281-1288, 2007. DOI: 10.1016/j.enconman. 2006.09.026.

[10] F. Daneshfar, H. Bevrani, "Load-frequency control: a GA-based multi-agent reinforcement learning", IET Generation, Transmission \& Distribution, vol. 4, no. 1, pp. 13-26, 2010. DOI: 10.1049/ietgtd.2009.0168.

[11] K. Jagatheesan, B. Anand, M. Ebrahim, "Stochastic particle swarm optimizaion for tuning of PID controller in load frequency control of single area reheat thermal power system", International Journal of Electrical and Power Engineering, vol. 8, no. 2, pp. 33-40, 2014. DOI: 10.3923/ijepe.2014.33.40. 
[12] A. Demiroren, H. L. Zeynelgil, N. S. Sengor, "The application of ANN technique to load-frequency control for three-area power system", in IEEE Porto Power Tech Proc., Porto, Portugal, 2001. DOI: 10.1109/PTC.2001.964793.

[13] R. Khanaki, M. A. M. Radzi, M. H. Marhaban, "Comparison of ANN and P\&O MPPT methods for PV applications under changing solar irradiation", in IEEE Conf. Clean Energy and Technology (CEAT 2013), Lankgkawi, Malaysia, 2013, pp. 287-292. DOI: 10.1109/CEAT.2013.6775642.

[14] M. R. Khalghani, M. H. Khooban, E. Mahboubi-Moghaddam, N. Vafamand, M. Goodarzi, "A self-tuning load frequency control strategy for microgrids: Human brain emotional learning", International Journal of Electrical Power \& Energy Systems, vol. 75 pp. 311-319, 2016. DOI: 10.1016/j.ijepes.2015.08.026.

[15] M. H. Khooban, T. Niknam, "A new intelligent online fuzzy tuning approach for multi-area load frequency control: self adaptive modified bat algorithm", Int. Journal of Electrical Power \& Energy Systems, vol. 71, pp. 254-261, 2015. DOI: 10.1016/j.ijepes.2015.03.017.

[16] S. Lalouni, D. Rekioua, "Optimal control of a grid connected photovoltaic system with constant switching frequency", Energy Procedia, vol. 36, pp. 189-199, 2013. DOI: 10.1016/j.egypro.2013.07.022.

[17] G. Sharma, Ibraheem, K. R. Niazi, R. C. Bansal, "Adaptive fuzzy critic based control design for AGC of power system connected via AC/DC tie-lines", IET Generation, Transmission \& Distribution, vol. 11, no. 2, pp. 560-569, 2017. DOI: 10.1049/iet-gtd.2016.1164.

[18] G. Merei, C. Berger, D. U. Sauer, "Optimization of an off-grid hybrid PV-Wind-Diesel system with different battery technologies using genetic algorithm", Solar Energy, vol. 97, pp. 460-473, 2013. DOI: 10.1016/j.solener.2013.08.016.

[19] M. F. Kashif, S. Choi, Y. Park, Seung-Ki Sul, "Maximum power point tracking for single stage grid-connected PV system under partia shading conditions", IEEE 7th Int. Power Electronics and Motion Control Conf., Harbin, 2012, pp. 1377-1383.

[20] M. S. Ismail, M. Moghavvemi, T. M. I. Mahlia, "Characterization of PV panel and global optimization of its model parameters using genetic algorithm", Energy Conversion and Management, vol. 73, pp. 10-25, 2013. DOI: 10.1016/j.enconman.2013.03.033.

[21] I. H. Altas, A. M. Sharaf, "A photovoltaic array simulation model for Matlab-Simulink GUI environment", in Int. Conf. Clean Electrical Power, Capri, Italy, 2007, pp. 341-345. DOI: 10.1109/ICCEP.2007.384234.

[22] A. M. Sharaf, A. A. A. El-Gamma, "A novel coordinated efficient gaself regulating PID controller for hybrid PV-FC-diesel-battery renewable energy scheme for household electricity utilization", in Fourth Asia Int. Conf. Mathematical/Analytical Modelling and Computer Simulation (AMS 2010), Bornea, Malaysia, 2010, pp. 456462. DOI: 10.1109/AMS.2010.94.

[23] I. H. Altas, A. M. Sharaf, "A novel maximum power fuzzy logic controller for photovoltaic solar energy systems", Renewable Energy, vol. 33, no. 3, pp. 388-399, 2008. DOI: 10.1016/j.renene.2007.03.002.

[24] I. Kocaarslan, E. Cam, "Fuzzy logic controller in interconnected electrical power systems for load-frequency control", Int. Journal of Electrical Power \& Energy Systems, vol. 27, no. 8, pp. 542-549, 2005. DOI: 10.1016/j.ijepes.2005.06.003.

[25] H. Gozde, M. C. Taplamacioglu, I. Kocaarslan, "A swarm optimization based load frequency control application in a two area thermal power system", in Int. Conf. Electrical and Electronics Engineering (ELECO 2009), Bursa, Turkey, 2009, pp. 124-128. DOI: 10.1109/ELECO.2009.5355221.

[26] E. Cam, G. Gorel, H. Mamur, "Use of the genetic algorithm-based fuzzy logic controller for load-frequency control in a two area interconnected power system", Applied Sciences, vol. 7, no. 3, p. 308, 2017. DOI: $10.3390 / a p p 7030308$

[27] G. Gorel, E. Cam, M. Luy, R. Gurbuz, "Operation of load frequency control with PID controller in single area renewable green photovoltaic energy systems", presented at the 1st Int. Conf. Environmental Science and Technology, Sarajevo, Bosnia and Herzegovina, 2015, pp. 313-318

[28] I. Sefa, N. Altin, S. Ozdemir, O. Kaplan, "Fuzzy PI controlled inverter for grid interactive renewable energy systems", IET Renewable Power Generation, vol. 9, no. 7, pp. 729-738, 2015. DOI: 10.1049/iet-rpg.2014.0404

[29] A. Mohanty, S. Patra, P. K. Ray, "Robust fuzzy-sliding mode based UPFC controller for transient stability analysis in autonomous winddiesel-PV hybrid system", IET Generation, Transmission \& Distribution, vol. 10 , no. 5, pp. 1248-1257, 2016. DOI: $10.1049 /$ ietgtd.2015.1000.

[30] H. Bevrani, F. Habibi, P. Babahajyani, M. Watanabe, Y. Mitani, "Intelligent frequency control in an AC microgrid: online PSO-based fuzzy tuning approach", IEEE Trans. Smart Grid, vol. 3, no. 4, pp. 1935-1944, 2012. DOI: d10.1109/TSG.2012.2196806.

[31] V. S. Vakula, K. R. Sudha, "Design of differential evolution algorithm-based robust fuzzy logic power system stabiliser using minimum rule base", IET Generation, Transmission \& Distribution, vol. 6, no. 2, pp. 121-132, 2012. DOI: 10.1049/iet-gtd.2011.0195.

[32] S. S. Dhillon, J. S. Lather, S. Marwaha, "Multi objective load frequency control using hybrid bacterial foraging and particle swarm optimized PI controller", International Journal of Electrical Power \& Energy Systems, vol. 79, pp. 196-209, 2016. DOI: 10.1016/j.ijepes.2016.01.012.

[33] C. Yadav, M. Singh, K. Tiwari, R. Tiwari, N. P. Chandra, "PID controller design using performance index parameter by PSO BFO techniques", International Journal of Innovative Research and Creative Technology, vol. 1, no. 2, 2015.

[34] N. H. Saad, A. A. El-Sattar, M. E. Marei, "Improved bacterial foraging optimization for grid connected wind energy conversion system based PMSG with matrix converter", Ain Shams Engineering Journal, 2017. DOI: 10.1016/j.asej.2017.03.010. 